obituary

\section{Sir Gerard Thornton}

Microbiologists, especially those who had the good fortune to work with him, will have heard with sadness of the death of Sir Gerard Thornton on 6 February at his home in St. Albans at the age of 85 . He is survived by his widow, Gerda, who is Danish, and by his son Peter who is Keeper of Woodwork and Furniture at the Victoria and Albert Museum.

$\mathrm{He}$ will be remembered for his many original and important studies on soil microbes, made in the course of a long career spent almost wholly at Rothamsted Experimental Station, Harpenden. $\mathrm{He}$ was educated at Radley and at New College Oxford and joined Rothamsted shortly after the end of the Great War where he had served as a pilot in the Royal Flying Corps.

In 1919, soil microbiology was a very rudimentary science, and Thornton's early work was much concerned with the devising of techniques for isolating, identifying and counting various kinds of soil bacteria and in promoting parallel studies by others on soil fungi, protozoa and other groups. With his friend the late R. A. Fisher he pioneered the application of statistics to the problems of enumerating bacteria in soil. At this time he was also in contact with the great European soil microbiologists-Beijerinck, Winogradsky, Kluyver and later with Waksman. $\mathrm{He}$ had a special interest in the microbial breakdown of aromatic disinfectants in soil, and made a collection of bacteria able to utilise cresols, phenols and naphthalene as sole carbon sources and elucidated some aspects of their physiology. This work was later to become specially relevant to the discovery, which he shared with others, of the selective hormone herbicides (chlorinated phenoxyacids), first published in Nature (155, 498; 1945).

His greatest influence, however, was through his distinguished research on biological nitrogen fixation, especially by root-nodulated leguminous plants. His detailed investigation of their microbiology, structure and physiology laid the foundation for nearly all later work and led to practical applications in UK agriculture. His work established the 'bacteroid' as the nitrogen fixing site in the nodule and he described in detail the features of ineffective, non. fixing nodules. With his Rothamsted colleagues he was the first to use sero- logical methods for identifying rhizobia and was associated with early work on bacteriophage and with studies on ecology of rhizobia. Thornton was also the first to investigate effects of competition between strains in the soil, a matter later shown to be important in the development of efficient 'inoculants' for leguminous crops. Since his retirement in 1957 he continued to show the greatest interest in nitrogen fixation and in the striking advances made world-wide in its study during the last decade, stimulated by the International Biological Programme and the energy crisis.

Thornton had wide interests in science and in the arts. He was especially interested in archaeology and in palaeontology and had the distinction of discovering a new species of plesiosaur (Rhomaleosaurus thorntonii) which can be seen at the British Museum, Natural History.

Thornton became head of the Department of Soil Microbiology in 1940. $\mathrm{He}$ was elected to the Fellowship of the Royal Society in 1941, of which he was Foreign Secretary from 1955-60 and a Vice-President in 1959-60. He was actively involved in the organisation of the Society's Tercentenary celebrations and was knighted in 1960 . He served on the Council of the Royal Society and on many bodies concerned with microbiology and with agriculture.

Thornton was a quiet, modest man, invariably considerate and courteous with a charm of manner rarely seen today. His colleagues remember him with respect and affection.

P. S. Nutman

\section{E. Wheeler}

DR D. E. WheEler who died on January 24, was a chemist who in twelve years as Managing Director of The Wellcome Foundation Limited and a further three as a Deputy Chairman was concerned particularly with the profitable translation, through development and production, of the fruits of scientific research into important drugs and vaccines. As President of the Association of the British Pharmaceutical Industry he was a leading figure during an era when regulations were being established in the wake of the thalidomide tragedy. His integrity, relied upon alike by those in industry, medicine and government, was a major factor in the harmonious and successful negotiations. As first-ever Chairman of the Spastics Society he brought together two organisations concerned with the welfare of spastics and presided over a massive expansion on the financial side, making possible the sponsorship of original research on a considerable scale.

Denis Wheeler was born in Bristol on 6 September, 1910, and graduated from Bristol University where he specialised in physical chemistry and carried out research work which led to a Ph.D. in 1934. He was awarded a Salters' Fellowship to study industrial organisation and practice in the United States. Part of the time was spent at Princeton University where he studied advanced physical chemistry. In later years he was to become Master of the Salters' Company and concerned with the continuation of this type of scientific exchange.

On his return to Britain he joined the research department of Imperial Chemical Industries (Explosives) Ltd where he eventually became technically responsible for all acid production throughout the ICI organisation in Great Britain. In 1940 he was appointed research and development director of Hardman and Holden Ltd, chemical manufacturers.

He joined the board of directors of The Wellcome Foundation Limited in January 1946, was appointed assistant managing director later that year, joint managing director in 1948, managing director in 1955 and a deputy chairman in 1967. He retired from the board for health reasons in 1970. He was awarded the CBE in 1965.

In his early years with the Wellcome Foundation, Dr Wheeler was concerned with the organisation of development as a specific function, ensuring that the discoveries of the research laboratories could be produced in the appropriate formulations and on a sufficient scale to be administered to large numbers of humans or animals throughout the world. Whereas the research laboratories of Wellcome had been largely independent of the commercial company, he was able to convince the scientists that their work could still retain its integrity and its impetus whilst being guided towards the discovery of essential medicines, the sale of which would provide the resources for further research.

D. W. Adamson 